SOCIAL SCIENCE RESEARCH

Thomas Plümper *

Vera E. Troeger **

\title{
External Effects of Currency Unions
}

\section{* University of Konstanz, Department of Political Science and Public Policy \\ ** Max-Planck-Institute for Research in Economic Systems}

SP || $2004-06$

April 2004

ISSN Nr. $0722-6748$

Research Area

Markets and Political Economy

Working Group

Institutions, States, Markets
Forschungsschwerpunkt

Markt und politische Ökonomie

Arbeitsgruppe

Institutionen, Staaten, Märkte 
Zitierweise/Citation:

Thomas Plümper, Vera E. Troeger, External Effects of

Currency Unions, Discussion Paper SP II 2004 - 06,

Wissenschaftszentrum Berlin, 2004.

Wissenschaftszentrum Berlin für Sozialforschung gGmbH,

Reichpietschufer 50, 10785 Berlin, Germany, Tel. (030) 25491 - 0

Internet: www.wz-berlin.de 


\title{
ABSTRACT
}

\section{External Effects of Currency Unions}

\author{
by Thomas Plümper and Vera E. Troeger *
}

Argument: The paper argues that the introduction of the Euro has considerably reduced de facto monetary policy autonomy in non-ECU members.

We start from a simple Mundellian model, in which currency unions raise economic efficiency but reduce monetary policy autonomy. Our main argument holds that governments in countries that did not join the currency union lose monetary policy autonomy if the establishment of a currency union increases the size of the key currency area. The increase in the size of the key currency area has two external effects on countries remaining outside the currency union: Firstly, it renders stable exchange-rates to the currency union slightly more important, because the value of goods imported from countries within the currency union increases and because the countries inside the union have more synchronized business cycles. Secondly and more importantly, we claim that any given change in the real interest-rate differential leads to an exchange-rate effect, which is larger the smaller the domestic currency area is relative to the key currency area. Consequently, governments in non-member countries have to pay a higher price if they seek to stimulate the domestic economy.

Hypotheses: a) Exchange-rate effects on changes in the real interest rate differential are larger, if currency areas are less equal in size. b) Outsider countries more closely follow the interest-rate policy of the currency union than they had previously followed the monetary policy of the anchor currency.

Empirics: We employ a panel-GARCH model to estimate the impact of changes in the key currency real interest rate on the real interest rate of other countries. Specifically, we analyze the influence of Germany's and the Eurozone's monetary policy on the monetary policy of Great Britain, Denmark, Norway, Sweden, and Switzerland.

Results: Our results support the assumptions underlying our model as well as our main argument. De facto monetary autonomy of countries remaining outside a currency union declines with the establishment of the union.

Keywords: Interest Rates, Monetary Policy Autonomy, Currency Unions, Bundesbank, European Central Bank

JEL Classification: E5, N1

\footnotetext{
* For helpful comments we wish to thank Helmut Lüthkepohl, Rick van der Ploeg, Hannes Winner and Tom Cusack. Ulrike Sabrina Krämer und Brooke Luetgert provided valuable research assistance. Earlier versions of this paper were presented in seminars at the European University Institute, Florence, the Ludwig-Maximilians-University, Munich, the Science Centre Berlin, the University of Freiburg, and the Midwest Political Science Association annual conference in Chicago, April 2004.
} 


\section{Externe Auswirkungen von Währungsunionen}

Der Artikel argumentiert, dass die Einführung des Euro die faktische geldpolitische Autonomie auch in Staaten reduziert hat, die der Europäischen Währungsunion nicht beigetreten sind. Das Argument basiert auf einem einfachen Mudellianischen Modell, in dem Währungsunionen die wirtschaftliche Effizienz steigern aber zugleich die geldpolitische Autonomie reduzieren. Wir zeigen über das Standardmodell hinaus, dass Länder, die der Währungsunion nicht beitreten, geldpolitische Autonomie einbüßen, wenn sich durch die Währungsunion die Größe des Leitwährungsraumes erhöht. Diese Vergrößerung des Leitwährungsraumes hat zwei Auswirkungen auf Länder außerhalb der Union: Erstens steigt die Bedeutung stabiler Wechselkurse leicht an, weil der Wert importierter Güter aus dem Währungsgebiet zunimmt und weil die Länder der Union stärker synchronisierte Konjunkturzyklen aufweisen als vor der Gründung der Währungsunion. Zweitens steigt durch die Vergrößerung der Leitwährung aber der Einfluss von Veränderungen der Zinsdifferenz auf die Wechselkurse zwischen Währungen außerhalb der Währungsunion und der Unionswährung an. Folglich müssen Länder eine stärkere Abwertung ihrer Währung hinnehmen, wenn sie die Zinsen senken, um die Konjunktur anzukurbeln.

Wir testen dieses Argument anhand der zwei Kernhypothesen: a) Wechselkurse reagieren umso stärker auf Veränderungen der Zinsdifferenz, je größer der Leitwährungsraum ist. b) Länder außerhalb der Währungsunion folgen der Geldpolitik der Union stärker, als sie der Geldpolitik der Leitwährung vor Gründung der Union folgten. Wir greifen auf Panel-GARCH Modelle zurück, um den Einfluss der Geldpolitik der EZB relativ zum Einfluss der Bundesbank auf die Geldpolitik in Großbritannien, der Schweiz, Norwegen, Dänemark und Schweden zu testen. Die empirische Analyse bestätigt die aus dem formalen Modell abgeleiteten Hypothesen. Die faktische geldpolitische Autonomie der Länder außerhalb der Währungsunion sinkt mit deren Etablierung. 


\section{Introduction}

The Euro is back on the political agenda: In the three European Union member countries that abstained from joining the European Currency Union (ECU), opposition against the introduction of the common currency seems to dwindle. After a long period of negative public sentiment and reluctance among political parties to push forward the issue, the introduction of the Euro in Sweden, Denmark and Great Britain has become a possibility.

Consider Britain, where the political debate has long since been dominated by the so-called Brown criteria, formulated by Gordon Brown, Chancellor of the Exchequer. Just after Labour came into power, Brown defined five criteria for Britain joining the Euro: Only if a) business cycles synchronize between Britain and Euroland, b) the British industry proofs its competitiveness vis-à-vis Europe, c) the Euro boosts FDI in Britain, d) the City's role as a main international financial centre can be maintained and e) growth and employment increase, will the UK surrender monetary sovereignty to the European Central Bank (ECB) in Frankfurt. Six years later, Euro-sceptic Brown admitted that - although four of the five criteria have not been met - significant progress in achieving cyclical convergence has been made. As a consequence, political front lines gradually vanish while some observers already expect a referendum on British EMU membership in 2006 (Economist June 14, 2003).

The Euro also brought back the idea of becoming EU member back into the discussion in Norway and Switzerland. In Norway, a dramatic shift in public opinion concerning EU membership has occurred within the last month. While in 2002 opponents of EU membership held a small majority, a mere 6 months later supporters of Norwegian EU membership are now twice as numerous as their opponents. One crucial element of the apparent turnaround in the public opinion has been the Euro: With an appreciating Krona, the introduction of the Euro became a central issue in public political debates. Some politicians not only favour the immediate introduction of the Euro, they also advocate an early introduction of the Euro - if necessary even before Norway becomes a full EU member and without 
being granted voice in the ECB's board of governors. In other words, Norway would "Euroize". 1

The recent debates in Great Britain and Norway raise questions about what has changed since only 12 out of 15 EU members could agree upon the European Currency Union (ECU). Why does it seem to be a different question whether a group of countries should push ahead with the creation of a single currency or whether it is in the interest of outsiders to join a currency union once it has come into being? Why do countries consider becoming part of Euroland that abstained from doing so only a decade before?

This paper gives an answer to these puzzling questions by analyzing the external effects of currency unions. We argue that the Euro gained significance on the political agenda in non-member countries, because the introduction of the Euro has considerably reduced de facto monetary policy autonomy in non-ECU members.

Since the maintenance of monetary policy autonomy provides a major incentive not to join a currency union, the reduction of de facto monetary policy autonomy should, ceteris paribus, shift the incentive to join the union upwards.

We start from a simple Mundellian model, in which currency unions raise economic efficiency but reduce monetary policy autonomy. Depending on the governments' relative weights on growth of per capita income and on macroeconomic volatility, governments may or may not choose to found a new or join an already existing currency union.

In a nutshell, our main argument contends that governments in countries that did not join the currency union, loose monetary policy autonomy if the establishment of a currency union increases the size of the key currency area. Why should this be the case? We argue that the increase in the size of the key currency area has two external effects on countries remaining outside the currency union: Firstly, it renders a stable exchange-rate to the currency union slightly more important because the value of goods imported from countries within the currency union in-

Eduardo Leyi Yeyati and Federico Sturzenegger (2003) dub all instances of countries accepting a foreign currency as 'Dollarization' - regardless of the currency involved. Note, that in only 14 of the 32 cases they report that the Dollar was accepted as sole means of payment. 
creases. This effect should be moderate and cannot be taken as granted because trade diversion effects in the union could render the union an even less important trading partner for outside countries. Secondly, the business cycle of countries within the currency union becomes more synchronized. As a consequence, it may become more important for outside countries to bring monetary policy broadly in line with the monetary policy of the union taken its won and the union's business cycles as given. Thirdly and probably most importantly, we claim that for any given change in the real interest-rate differential (suppose this change is caused by active monetary policy) leads to an exchange-rate effect, which is the larger the smaller the country is in relation to the key currency area. ${ }^{2}$ Since the foundation of a currency union that is joined by the former key currency inevitably increases the size of the key currency area, outside countries get relatively smaller. Consequently, governments in non-member countries have to pay a larger price if they seek to stimulate the domestic economy.

We use a combination of the second and the third effect to explain why outside countries more closely follow the interest-rate policy of the currency union than they had followed the monetary policy of the previous anchor currency. This model is developed in more detail in section 2. Section 3 tests the causal mechanism of the model along with the implications of the model for monetary policy autonomy in non-member countries. Our empirical test case is provided by the European currency union. Specifically, we analyze the central bank interest rates of three EU members who did not sign the European Monetary Union treaty (Great Britain, Denmark and Sweden) and the two EFTA countries (Norway and Switzerland) to test our hypothesis of an EMU-induced decline in monetary policy autonomy among non-Euroland countries. Finally, section 4 concludes with a broader discussion of the emerging strategic setting and the policy implications of our analysis.

\section{The Model}

According to Robert Mundell's path-breaking model of optimal currency areas (Mundell 1961; see also McKinnon 1963 and Kenen 1969), currency unions have two opposing consequences: On the one hand, member states benefit because a

2 This logic directly follows from the Metzler diagram (Metzler 1960). 
joint currency lowers trading costs and thereby generates efficiency gains. The credibility of the central bank is enhanced and the country's risk rating declines. On the other hand, a single currency precludes the implementation of independent monetary policies. Once a country joins a currency union, monetary policies can no longer be tailored to country-specific economic shocks (Mundell 1961, 1965). The currency union not only reduces the number of policy instruments available to the government, governments also lose their ability to act as lender of last resort, simply because they can no longer print money to provide markets with liquidity (Broda and Levy Yeyati 2003).

With one notable exception, the model developed here follows the logic of Alberto Alesina's and Robert Barro's recent formalization of the Mundellian model of currency unions (Alesina/ Barro 2002). While Alesina and Barro ignore exchange-rate effects, our model explicitly accounts for them.

The intuition of the model captures the idea that the de facto monetary policy autonomy of countries remains incomplete even if governments maintain legal authority over monetary policy. The idea of non-legal limits to monetary autonomy is nothing new in the literature. For instance, Kaminsky and Reinhart claim that once a monetary authority has lost its credibility in fighting inflation, it will probably face serious difficulties in counterbalancing economic shocks (Kaminsky/ Reinhart 1999). In addition, Jay Shambaugh (2004) argues that all countries, not just pegged countries and members of a currency union, lack monetary policy autonomy. Shambaugh holds that de facto monetary policy autonomy is most restricted in small countries (p. 304), but he also shows that the monetary authorities of pegged countries react more quickly to changes in the key currency area's monetary policy (p. 344). Thus, even if the monetary authority is legally unrestricted, it faces severe constraints in actually reaching its policy goals. Our analysis takes one step beyond the common wisdom just discussed. We hold that monetary authorities face a trade off between stabilizing the exchange-rate and moderating the macroeconomic effects of an exogenous demand shock. Monetary authorities therefore target two policy goals with one instrument.

Most importantly, our model makes the case that the resulting trade-off between exchange-rate stability and macroeconomic performance is a function of the size of the key currency area for two reasons: Firstly, the larger the key currency area, 
the more intermediate goods are imported from that currency zone. Accordingly, a stabilization of the exchange-rate becomes a prerequisite of flourishing trade relations. Second and more importantly, the change in the difference between the domestic and the foreign real interest rates being equal, an upward shift in the size of the currency area potentially leads to larger changes in the bilateral exchange-rate. Thus, the larger the key currency area, the more elastically the exchange rate will react to changes in the interest rate differential.

If this assertion is valid (we will test this proposition in the empirical section), the establishment of a currency union may shift the political balance between macroeconomic stimulation and exchange-rate stabilization in favor of the latter policy goal. If the currency union increases the size of the key currency area, non-members partly lose the interest-rate as an instrument to stimulate the economy. Relatively small countries have a larger interest in exchange-rate stability. Hence, de facto monetary policy autonomy (the extent to which a monetary authority uses its policy instruments to stimulate the economy) decreases with the size of the key currency area. The remainder of this section restates this logic within a standard model of a currency union.

\section{Modelling Gains from Trade}

Consider a simple economy in which competitive firms produce using a DixitStiglitz production function (Dixit/ Stiglitz 1977). The output of firm $i$ is given by

$$
y_{i}=A L_{i}^{1-\alpha} \sum_{j=1}^{N} X_{j i}^{\alpha} \quad, 0<\alpha<1
$$

where $A>0$ measures productivity, $L_{i}$ is the firm's employment of labour and $X_{j i}$ is the amount of intermediate goods used by firm $i$. Countries $I$ and $I I$ produce non-overlapping intermediaries. Domestic and foreign producers of intermediate goods do not compete, though both national markets may be competitive. Within each country markets are perfect; there are no transportation costs or political market distortions. Shipping between the two countries, on the contrary, includes transportation costs $0<b<1$ as a result of distance, costs of hedging against exchange rate-risks, use of a different language, dissimilarity in legal systems (stan- 
dards), and cultural heterogeneity. ${ }^{3}$ These costs reflect the use of resources and are sunk. $^{4}$

Controlling for mark-up prices of the intermediates $1 \leq \mu_{j} \leq 1 / \alpha$, the absolute value of intermediates employed by firm $i$ in country $I$ is given by

$$
\begin{aligned}
& X_{j i}=\left(A \alpha / \mu^{I}\right)^{1 /(1-\alpha)} L_{i}, j=1, \ldots, N^{I} \\
& X_{j i}=\left[\left(A \alpha / \mu^{I I}\right)(1-b)\right]^{1 /(1-\alpha)} L_{i}, j=N^{I}+1, \ldots, N
\end{aligned}
$$

where $j=1, \ldots, N^{I}$ denotes the intermediates produced in country $I$ while country II produces the intermediates $j=N^{I}+1, \ldots, N$. The smaller the trading cost, the higher the absolute input of foreign intermediates and the higher the relative share of foreign intermediates will be. Small open economies gain more from joining a currency union than their larger trading partners because most of their intermediates are produced abroad.

At this point, we depart from the Alesina-Barro model (Alesina/ Barro 2002) by assuming that mark-up prices result not only from changes in total demand but also from exchange-rate effects. In the presence of exchange-rate adjustments, mark-up prices differ in country $I$ and $I I$. Specifically, once a government uses monetary policy instruments to stimulate the economy and counterbalance exogenous shocks, its currency depreciates vis-à-vis the key currency and hence the price of imported goods (measured in the domestic currency) rises.

Welfare gains from trade are then

$$
\frac{C^{I}}{N^{I}}=A^{1 /(1-\alpha)} \alpha^{\alpha /(1-\alpha)}\left[\begin{array}{l}
\left(\mu^{I}-\alpha\right)\left(1 / \mu^{I}\right)^{1 /(1-\alpha)} N^{I} \\
+\left(\mu^{I I}-\alpha\right)\left(1 / \mu^{I I}\right)^{1 /(1-\alpha)}(1-b)^{\alpha /(1-\alpha)} N^{I I}
\end{array}\right]
$$

Welfare gains are maximized if $\mu=1$ (the mark-up costs of intermediates are minimal) and $b=0$ (there are no international transaction costs). The larger $b$ and the larger the price effect of trade, the smaller the welfare gains will be for country $I$. Since the costs of a currency union have not yet been dealt with, equation 3 plausibly suggests that welfare is maximized if the world consisted of only one 
country (Alesina/ Barro 2002: 416). However, this conclusion depends on restrictive ceteris paribus assumptions that will be relaxed in subsequent sections. Ignoring omitted side-effects for the time being, the gross gains from joining a currency union are

$\frac{\partial C^{I}}{\partial(1-b)}=\frac{\alpha}{1-\alpha}(1-b)^{(2 \alpha-1) /(1-\alpha)} N^{I I} A^{1 /(1-\alpha)} \alpha^{\alpha /(1-\alpha)}\left(\mu^{I I}-\alpha\right)\left(1 / \mu^{I I}\right)^{1 /(1-\alpha)} N^{I}>0$

The next section considers the costs of joining a currency union more closely. Once these costs are introduced, the optimal number of currencies exceeds one.

In equation 4 all single components are positive. Thus, the whole term is also strictly positive. This suggests that gains from joining a currency union are higher, the higher transaction costs of having more than one currency are. Accordingly, countries are more likely to form a currency union when exchange-rates are more volatile and when it is difficult to find domestic substitutes for imported intermediates.

\section{Modelling Gains from Macroeconomic Policy Autonomy}

This subsection analyzes the gains from macroeconomic policy autonomy. We employ a standard textbook model of monetary policy, ${ }^{5}$ where economic agents rationally expect the inflation rate $\pi^{e}$, which is a function of the natural rate of unemployment and the expected monetary policy $\pi^{e}=\mathrm{E}(\pi \mid \theta)=\mathrm{E}(m \mid \theta) . \theta$ stands for the natural rate of unemployment, $m$ is monetary policy, and $\mathrm{E}$ denotes the expectation term.

Actors adjust their behavior according to all available information. As a natural consequence, monetary policy cannot 'create' output growth and employment. Rather, in the absence of international monetary policy spill-overs monetary authorities have an incentive to set $\mathrm{m}$ according to the non-accelerating inflationary rate of unemployment (NAIRU). Thus, the optimal monetary policy reduces inflation at acceptable levels while at the same time stabilizing the unemployment rate.

$5 \quad$ Notation is based on Persson/ Tabellini 2000. 
Governments can nevertheless stabilize employment by responding to unexpected exogenous shocks of size $\varepsilon$. If a government keeps monetary policy constant in the presence of an exogenous shock, unemployment increases while inflation remains constant. However, the government can also adjust monetary policy according to the exogenous shock, that is, it may reduce the central bank interest rate. Thereby, the drop in consumption and the increase in unemployment both are minimized, while inflation remains constant because rational agents anticipate a reversal of monetary policy once the exogenous shock is over.

Keeping this in mind, change in consumption follows

$$
C^{I}=[1+(m-\mathrm{E}(m \mid \theta)-\varepsilon)] \bar{C}^{I},
$$

where $\varepsilon$ is a stochastic element (say: a supply shock of intermediate goods) with mean 0 and an unproblematic variance. $\bar{C}^{I}$ denotes the consumption rate which is reached in the simultaneous absence of exogenous shocks and active monetary policies.

Inserting (5) in (3) gives:

$$
\begin{aligned}
\frac{C^{I}}{N^{I}}= & {[1+(m-\mathrm{E}(m \mid \theta)-\varepsilon)] \times } \\
& {\left[\begin{array}{l}
A^{1 /(1-\alpha)} \alpha^{\alpha /(1-\alpha)}\left[\begin{array}{l}
\left(\mu^{I}-\alpha\right)\left(1 / \mu^{I}\right)^{1 /(1-\alpha)} N^{I} \\
+\left(\mu^{I I}-\alpha\right)\left(1 / \mu^{I I}\right)^{1 /(1-\alpha)}(1-b)^{\alpha /(1-\alpha)} N^{I I}
\end{array}\right]
\end{array}\right], }
\end{aligned}
$$

where the effects of an unexpected exogenous shock are given by

$$
\frac{\partial C^{I}}{\partial \varepsilon}=-\left[A^{1 /(1-\alpha)} \alpha^{\alpha /(1-\alpha)}\left[\begin{array}{l}
\left(\mu^{I}-\alpha\right)\left(1 / \mu^{I}\right)^{1 /(1-\alpha)} N^{I} \\
+\left(\mu^{I I}-\alpha\right)\left(1 / \mu^{I I}\right)^{1 /(1-\alpha)}(1-b)^{\alpha /(1-\alpha)} N^{I I}
\end{array}\right]\right]<0
$$

in case the government does not counterbalance the shock. The potential gains from monetary policy autonomy are then given by

$$
\frac{\partial C^{I}}{\partial m}=\left[A^{1 /(1-\alpha)} \alpha^{\alpha /(1-\alpha)}\left[\begin{array}{l}
\left(\mu^{I}-\alpha\right)\left(1 / \mu^{I}\right)^{1 /(1-\alpha)} N^{I} \\
+\left(\mu^{I I}-\alpha\right)\left(1 / \mu^{I I}\right)^{1 /(1-\alpha)}(1-b)^{\alpha /(1-\alpha)} N^{I I}
\end{array}\right]\right]>0
$$

Since potential losses in individual consumption are a function of the severity of the exogenous shock, governments intervene more strongly into the markets when shocks are severe. Perhaps being overly optimistic the model implies that if gov- 
ernments fully offset the consequences of an exogenous shock, individual consumption does not decline at all. In reality, however, governments may not completely eliminate the effects of economic shocks, because the use of monetary policy pushes up the agents' interest rate expectation. Following mainstream political economy (Persson/ Tabellini 2000) and assuming that governments maximize a quadratic support function $S_{g}=-(1-\lambda)(\pi-\bar{\pi})^{2}-\lambda(x-\bar{x})^{2}$, the political reaction to a supply shock $\varepsilon>0$ depends on the value of lambda $(0 \geq \lambda \geq 1)$. $\bar{\pi}$ and $\bar{x}$ denote society's most preferred values of inflation and employment. In the absence of capital flows, the optimal monetary policy is $m_{o p t}=\bar{\pi}+\lambda \varepsilon$.

Due to this trade-off between counterbalancing the economic shock and rising inflation expectation, governments do not necessarily annul the effect of exogenous shocks. They also calculate the influence of changes in monetary policy on the inflation expectation. Specifically, the more important output and employment for the government's survival in power, the more the government cuts interest rates or increases the money supply in reaction to unexpected exogenous shocks.

The model specification discussed so far brings about some straightforward results: Firstly, if - say - left wing governments value monetary policy autonomy more than their conservative counterparts do, they are less keen to join a monetary union. Moreover, the incentive to join a monetary union should decline with the societal desire to fight unemployment. And secondly, the less a government can commit itself to an anti-inflationary policy, the higher is the incentive to join a currency union (Chang/ Velasco 2000).

Before we turn to discussing the external effects of currency unions, we summarize the predictions made by the model: Countries are more likely to join a currency union, a) the more their production process relies upon imported intermediate goods, b) the smaller and more open they are, c) the less efficient financial markets cope with exchange-rate risks, d) the more frequent and severe unexpected economic shocks are, and e) the more the population values consumption relative to low levels of inflation. 
Gains from monetary policy autonomy in the presence of exchange-rate adjustments

In the presence of exchange-rate adjustments monetary policy becomes less desirable. If the government cuts interest rates, capital outflows intensify and the domestic currency devaluates. The same happens if the government prefers to augment the money supply: Under this condition, agents expect an increase in the inflation rate, which in turn weakens the exchange-rate. Hence, active monetary policies raise the price of imported intermediates - thereby inevitably reducing the stimulating effects of government intervention. Because smaller countries import larger shares of intermediate goods, monetary policy autonomy is least valuable in small and open economies. Governments in small countries for these reasons place a higher value on avoiding exchange-rate effects and shy away from active monetary policy.

Our main argument holds that the extent of exchange-rate adjustments and therefore the mark-up price effect is positively related to the size of the key currency area. Since the establishment of a currency union may push the size of the key currency area upward (as it happened in Europe after the foundation of the ECU), governments shift the political balance between macroeconomic stimulation and exchange-rate stabilization in favor of the former policy goal. De facto monetary policy autonomy (the extent to which a monetary authority uses its policy instruments to stimulate the economy) decreases with the size of the key currency area.

To explicitly model the logic of our argument, we let the mark-up price of the foreign intermediates partly depend on the monetary policy of country $I$ plus the size of country $I$ relative to the size of the key currency area. If the central bank untightens domestic monetary policy to offset exogenous shocks the price of foreign intermediates rises due to capital outflow and subsequent exchange rate adjustments:

$\mu^{I I}=\mu^{I}+i^{I I}-i^{I}-\Delta \frac{e^{I I}}{e^{I}}$

where $i^{I}, i^{I I}$ are the interest rates of country $I$ and $I I$ respectively and $\Delta \frac{e^{I}}{e^{I I}}$ denote exchange rate adjustments. 


$$
\frac{\partial \mu^{I I}}{\partial i^{I}}<0 \quad ; \quad \frac{\partial \mu^{I I}}{\partial\left(\Delta \frac{e^{I I}}{e^{I}}\right)}<0
$$

The price of foreign intermediates increases as the domestic monetary authority cuts the interest rate. Governments employing monetary policy instruments do not only counterbalance exogenous shocks; they indirectly trigger capital exports. This unintended but hardly avoidable side-effect devaluates the domestic currency and thereby renders imported intermediates more expensive.

Equation 11 computes the change in the consumption level of country $I$ as a function of the mark-up price of intermediaries produced in country $I I$ :

$$
\begin{aligned}
\frac{\partial C^{I}}{\partial \mu^{I I}}= & \frac{\alpha}{1-\alpha}\left[\left(\mu^{I I}\right)^{\frac{-2+\alpha}{1-\alpha}}-\left(\mu^{I I}\right)^{\frac{-1}{1-\alpha}}\right](1-b)^{\alpha /(1-\alpha)} N^{I I} N^{I} A^{1 /(1-\alpha)} \alpha^{\alpha /(1-\alpha)} \\
& \times[1+(m-\mathrm{E}(m \mid \theta)-\varepsilon)]<0
\end{aligned} .
$$

Since $\left(\mu^{I I}\right)^{\frac{-1}{1-\alpha}}$ is larger than $\left(\mu^{I I}\right)^{\frac{-2+\alpha}{1-\alpha}}$ for $0<\alpha<1$, the whole term is always negative. Accordingly, domestic consumption declines as the prices for foreign intermediates rise. More importantly, the smaller a country's currency is relative to the size of the key currency area, the less monetary policy stimulates the economy. Since we are especially interested in this relationship, we compute the second partial derivatives of individual domestic consumption with respect to monetary policy/mark-up prices of foreign intermediates and with respect to the relative size of the currency union:

$$
\begin{aligned}
\frac{\partial^{2} C^{I}}{\partial \mu^{I I} \partial N^{I I}}= & \frac{\alpha}{1-\alpha}\left[\left(\mu^{I I}\right)^{\frac{-2+\alpha}{1-\alpha}}-\left(\mu^{I I}\right)^{\frac{-1}{1-\alpha}}\right](1-b)^{\alpha /(1-\alpha)} N^{I} A^{1 /(1-\alpha)} \alpha^{\alpha /(1-\alpha)} \\
& \times[1+(m-\mathrm{E}(m \mid \theta)-\varepsilon)]<0
\end{aligned}
$$

Apparently, the stimulating effect of monetary policy autonomy declines when the key currency area expands. Governments may nevertheless continue to utilize monetary policy instruments in the presence of a neighbouring monetary union. The price tag attached to stimulating the economy, however, becomes larger after other countries agree to a unified monetary policy. Once a currency union is established, governments of non-member countries either realize a smaller macro- 
economic effect of interest-rate cuts or have to accept higher inflation rates. Overall, an increase in the size of the key currency (caused by the formation of a currency union) makes monetary policy for outside countries more costly. In other words: De facto monetary policy autonomy declines when the size of the key currency area increases.

\section{The Effect of Currency Unions on the Monetary Policy of Outsiders: Empirical Analysis}

We test the hypotheses derived from the formal model by analysing the influence of the EMU on EU members abstaining from the European Currency Union and later the Euro (Great Britain, Sweden and Denmark) and on two EFTA countries (Norway, Switzerland). Before examining the implication of our model in-depth, we demonstrate the validity of the underlying assumption. Again, our argument postulates that the size of the key currency area influences the impact of a change in the real interest differential. If this did not hold, our theory would rest on a wrong assumption and testing the main hypothesis would make little sense.

In a second step we employ panel GARCH models to directly estimate the effect of changes in the key currency area's interest rate on the interest rates of the countries outside the union. Since daily data is not available for our control variables, we examine monthly data. Our sample spans the time from 1973 to 2002. The first year of observation is of limited importance; changes in the first considered data-point do not alter the results.

To investigate the external effects of a currency union systematically, we examine the determinants of the discount rate (,the rate at which the central banks lend or discount eligible paper for deposit money banks") and the lending rate (,the rate that usually meets the short- and medium-term financing needs of the private sector"). In particular, we analyze discount rate adjustments in the cases of the Scandinavian countries Denmark, Norway and Sweden and lending rates in the cases of Great Britain and Switzerland. Because information on both interest rates is available for Germany, it was possible to regress discount rates on discount rates and lending rates on lending rates. Under this condition, we were unable to observe parameter heterogeneity between the two subsets of countries. 
Table 1 displays the summary statistics of the central bank interest rates for the five countries included in our sample and for Germany:

\begin{tabular}{|l|rrrrrc|}
\hline & Mean & Maximum & Minimum & Std. Dev. & Obs. & Period \\
\hline \multicolumn{2}{|l}{ discount rates } \\
\hline GER & 4.596 & 8.750 & 1.950 & 1.804 & 357 & $73: 01-02: 09$ \\
DNK & 7.251 & 13.000 & 2.750 & 2.553 & 356 & $73: 01-02: 08$ \\
NOR & 8.556 & 17.000 & 4.500 & 2.544 & 357 & $73: 01-02: 09$ \\
SWE & 6.891 & 12.000 & 1.000 & 2.975 & 355 & $73: 01-02: 07$ \\
\hline \multicolumn{2}{ll}{ lending rates } \\
\hline GER & 10.347 & 15.440 & 7.270 & 1.952 & 305 & $77: 05-02: 09$ \\
GBR & 9.378 & 17.000 & 4.000 & 3.208 & 356 & $73: 01-02: 08$ \\
CHE & 5.471 & 7.990 & 3.800 & 1.133 & 261 & $81: 01-02: 09$ \\
\hline
\end{tabular}

Table 1: Summary Statistics of Central Bank Interest Rates

Though lending rates are higher than discount rates, we were unable to detect a systematic effect in the regression analyses. Our results are therefore robust in the operationalization of the central bank interest rate. ${ }^{6}$

\section{The Effect of Changes in the Interest Rate Differential on the Exchange-Rate}

We start with a test of the assumption that the effect of changes in the interest rate differences on the exchange-rate increases with the size of the key currency area. This test is necessary, because we are not aware of research relating exchange-rate effects to interest-rate differentials and the relative sizes of currency areas.

Neither have pre-tests indicated the existence of serial and cross-sectional heteroscedasticity, nor were usual statistical tests able to detect autocorrelation. ${ }^{7}$ The absence of these common econometric plagues allows us to run a simple panel regression of exchange rate adjustments to Germany and the Eurozone on changes of interest rate differences with Germany (model 1) and the interest rate changes of the outsider countries (model 2). Our assumptions are valid if the observed effect is larger after the establishment of the ECU. Table 2 depicts the results:

\footnotetext{
$6 \quad$ We used simple sample split methods and more complex interaction effect specifications to test the dependency of our results on the type of interest rates reported by the central banks. We found no systematic effect. Results can be obtained from the authors upon request.

7 Test statistics will be provided upon request
} 


\begin{tabular}{|l|c|c|}
\hline $\begin{array}{l}\text { dependent variable: } \\
\text { changes of exchange rate with } \\
\text { Germany /EURO }\end{array}$ & Model 1 & Model 2 \\
\hline Intercept & $\begin{array}{c}0.004 \\
(0.001)^{* * *}\end{array}$ & $\begin{array}{c}0.004 \\
(0.001)^{* * *}\end{array}$ \\
\hline $\begin{array}{l}\text { Changes in interest rate differences } \\
d\left(r_{i}-r_{\text {ger }}\right), 73-94\end{array}$ & 0.002 \\
\hline $\begin{array}{l}\text { Changes in interest rate differences } \\
d\left(r_{i}-r_{\text {ger }}\right), 94-02\end{array}$ & $0.003)$ & \\
\hline $\begin{array}{l}\text { Changes in interest rate of outsider } \\
\text { countries } d\left(r_{i}\right), 73-94\end{array}$ & $(0.008)^{* * * *}$ & 0.0001 \\
\hline $\begin{array}{l}\text { Changes in interest rate of outsider } \\
\text { countries } d\left(r_{i}\right), 94-02\end{array}$ & & $(0.003)$ \\
\hline prob. $<\mathrm{F}$ & & 0.035 \\
\hline $\mathrm{N}$ & 0.003 & $0.009)^{* * * *}$ \\
\hline
\end{tabular}

Table 2: Dependence of the exchange rate on interest rate differences before and after 1994

Table 2 provides ample evidence in support of our assumption. The effect of changes in the interest rate difference on the exchange rate is significantly more pronounced in the second period than in the first period. This result is robust and does not depend on whether changes in interest rate differences or changes in interest rate levels are used as regressors. The relationship between interest rates and exchange rates, upon which our model crucially relies, can easily be found in real world data. This clearly allows us to proceed with empirically testing of the main hypothesis derived from our model.

\section{Results from Panel GARCH Estimation in Differences}

To test our main theoretical assertion of an increase in the extent to which the monetary policy of the key currency area influences the interest rate of neighbouring countries, we run a panel GARCH model. Interest rates are usually driven by stochastic processes (that is: they have a single unit root), it is therefore recommended to take the first difference. By looking only at changes of the real interest rates, we reduce the available cross-sectional variance, but at the same time we get rid of the differences in levels resulting from different types of central bank interest rates and eliminate non-stationarity in the data. Unit roots render the 
estimated coefficients of time series models in levels inefficient and can even lead to spurious regression results. In our case, this is almost warranted, because our dataset includes far more time-points than cross sectional observations (countries). Most importantly, the procedure is also theoretically plausible, since we are interested in short term adjustments rather than in long-term effects. Consequently, we employ real interest rates (central bank interest rate minus the inflation rate) to eliminate noisy short-term variations in the inflation rate.

The variance of the dependent interest rates reveals time-dependency, thus violating one of the Gauss-Markov assumptions of linear regression models. Not controlling for variance heterogeneity would render estimates biased and inefficient though still consistent (Wooldridge 2003: 416). For this reason, we run Panel-GARCH (generalized autoregressive conditional heteroscedasticity) models, which do not only estimate the usual mean equation of linear models but also specify a variance equation. While the conditional mean function estimates the expected values of the endogenous variable with respect to our theoretical inspired exogenous variables (the German interest rate, domestic inflation, growth etc.), the variance equation controls for time-dependency of the endogenous variable's variance by regressing the variance of the endogenous variable on the lagged values of the squared residuals (ARCH-term) plus the lagged values of the forecasted variance (GARCH-term).

We regress real interest rate changes of Great Britain, Sweden, Denmark, Switzerland, and Norway on the real interest rate changes of the key currency (Germany/ Eurozone). Our theory finds support if the outsiders' monetary policy follows the real interest rates of the Eurozone more closely than it followed Germany's interest rate before the establishment of the Euro. We therefore estimate the slopes of our main variable for two (model 3), or respectively for four (model 4) periods. The cuts in the time-series have been specified for basically two purposes: The first reason is substantive: In July 1990, the EMU countries fully liberalized capital accounts vis-à-vis each other and enforced their monetary policy coordination. In January 1994, central banks of the EMU began to coordinate and harmonize interest rate policies more closely. At the same time, the European System of Central Banks was legally introduced. Finally, in January 1999, the EMU countries fixed their exchange-rate and introduced the Euro. The second 
reason is methodical: The earlier a unified 'key currency area' is assumed to come into existence, the stronger the test to our theory. The later the cut is set, the easier it is to find support for our theory. ${ }^{8}$

We control for the growth of GDP and the level of the real interest rate in the countries under observation as well as for the German growth rate and changes in the exchange rate. These variables are likely to influence the central bank interest rate, but are unlikely to be correlated with the main variables of interest. Thus, the exclusion of controls is possible in principle, though this would render the results less convincing. To further investigate the robustness of our findings, we report results from a model that controls for unit fixed effects. As some authors speculate, unit fixed effects might control for not explicitly modelled country specific time invariant variables (like institutions). Neither the inclusion or exclusion of control variables nor the inclusion of N-1 country dummies has substantial effects on the estimated coefficients of our theoretically interesting variables.

Table 3 reports all regression results in the $\operatorname{GARCH}(1,1)$ specification. The standard errors are displayed in parentheses.

8 We also ran the regressions excluding the period of the German unification 90-94.

Perhaps surprisingly, the inclusion/exclusion of these years does not alter the results. 


\begin{tabular}{|c|c|c|c|c|c|c|}
\hline $\begin{array}{l}\text { Dependent variable: } \\
\text { changes of real interest } \\
\text { rates of non-EMU } \\
\text { countries }\end{array}$ & Model 3 & Model 4 & Model 5 & Model 6 & Model 7 & Model 8 \\
\hline \multicolumn{7}{|l|}{ Mean Equation: } \\
\hline Intercept & $\begin{array}{c}-0.087 \\
(0.017) * * * *\end{array}$ & $\begin{array}{c}-0.087 \\
(0.017) * * * *\end{array}$ & $\begin{array}{c}-0.087 \\
(0.017) * * * *\end{array}$ & $\begin{array}{c}-0.110 \\
(0.027) * * * *\end{array}$ & $\begin{array}{c}-0.090 \\
(0.018) * * * *\end{array}$ & $\begin{array}{c}-0.116 \\
(0.039) * * *\end{array}$ \\
\hline $\begin{array}{l}\text { Level of Real Interest Rate } \\
\text { (GB, DNK, SWE, CHE, } \\
\text { NOR) }\end{array}$ & $\begin{array}{c}0.032 \\
(0.004) * * * *\end{array}$ & $\begin{array}{c}0.032 \\
(0.004) * * * *\end{array}$ & $\begin{array}{c}0.032 \\
(0.004) * * * *\end{array}$ & $\begin{array}{c}0.033 \\
(0.004) * * * *\end{array}$ & $\begin{array}{c}0.033 \\
(0.004) * * * *\end{array}$ & $\begin{array}{c}0.033 \\
(0.004) * * * *\end{array}$ \\
\hline $\begin{array}{l}\text { Change in Interest Rate } \\
\text { Germany, 73-94 }\end{array}$ & $\begin{array}{c}0.234 \\
(0.024) * * * *\end{array}$ & & $\begin{array}{c}0.234 \\
(0.024) * * * *\end{array}$ & $\begin{array}{c}0.229 \\
(0.025) * * * *\end{array}$ & $\begin{array}{c}0.231 \\
(0.025) * * * *\end{array}$ & $\begin{array}{c}0.230 \\
(0.025) * * * *\end{array}$ \\
\hline $\begin{array}{l}\text { Change in Interest Rate } \\
\text { Germany } 94-02\end{array}$ & $\begin{array}{c}0.311 \\
(0.082) * * * * \\
\end{array}$ & & $\begin{array}{c}0.310 \\
(0.083) * * * * \\
\end{array}$ & $\begin{array}{c}0.319 \\
(0.095) * * * * \\
\end{array}$ & $\begin{array}{c}0.309 \\
(0.082) * * * * \\
\end{array}$ & $\begin{array}{c}0.312 \\
(0.082) * * * * \\
\end{array}$ \\
\hline $\begin{array}{l}\text { Change in Interest Rate } \\
\text { Germany, } 73-90\end{array}$ & & $\begin{array}{c}0.210 \\
(0.051) * * * *\end{array}$ & & & & \\
\hline $\begin{array}{l}\text { Change in Interest Rate } \\
\text { Germany, 90-94 }\end{array}$ & & $\begin{array}{c}0.251 \\
(0.026) * * * *\end{array}$ & & & & \\
\hline $\begin{array}{l}\text { Change in Interest Rate } \\
\text { Germany, 94-99 }\end{array}$ & & $\begin{array}{c}0.304 \\
(0.112) * * *\end{array}$ & & & & \\
\hline $\begin{array}{l}\text { Change in Interest Rate } \\
\text { Germany, 99-02 }\end{array}$ & & $\begin{array}{c}0.317 \\
(0.119) * * *\end{array}$ & & & & \\
\hline Growth & & & & $\begin{array}{c}0.005 \\
(0.008)\end{array}$ & & \\
\hline Growth Germany & & & & $\begin{array}{c}0.006 \\
(0.011)\end{array}$ & & \\
\hline Change in Exchange-Rate & & & $\begin{array}{c}0.060 \\
(0.227)\end{array}$ & $\begin{array}{c}0.042 \\
(0.233)\end{array}$ & & \\
\hline FE Sweden & & & & & & $\begin{array}{c}0.020 \\
(0.047)\end{array}$ \\
\hline
\end{tabular}




\begin{tabular}{|c|c|c|c|c|c|c|}
\hline FE Denmark & & & & & & $\begin{array}{c}0.041 \\
(0.042)\end{array}$ \\
\hline FE Switzerland & & & & & & $\begin{array}{c}0.016 \\
(0.051)\end{array}$ \\
\hline FE Norway & & & & & & $\begin{array}{c}0.050 \\
(0.047) \\
\end{array}$ \\
\hline MA $1\left(\varepsilon_{t-1}\right)$ & & & & & $\begin{array}{c}0.022 \\
(0.030)\end{array}$ & \\
\hline \multicolumn{7}{|l|}{ Variance Equation: } \\
\hline Intercept & $\begin{array}{c}0.019 \\
(0.001) * * * *\end{array}$ & $\begin{array}{c}0.019 \\
(0.001) * * * *\end{array}$ & $\begin{array}{c}0.019 \\
(0.001) * * * *\end{array}$ & $\begin{array}{c}0.021 \\
(0.001) * * * *\end{array}$ & $\begin{array}{c}0.019 \\
(0.001) * * * *\end{array}$ & $\begin{array}{c}0.019 \\
(0.001) * * * *\end{array}$ \\
\hline $\mathrm{ARCH} 1\left(\varepsilon_{t-1}^{2}\right)$ & $\begin{array}{c}0.161 \\
(0.013) * * * *\end{array}$ & $\begin{array}{c}0.160 \\
(0.013) * * * *\end{array}$ & $\begin{array}{c}0.161 \\
(0.013) * * * *\end{array}$ & $\begin{array}{c}0.159 \\
(0.013) * * * *\end{array}$ & $\begin{array}{c}0.163 \\
(0.013) * * * *\end{array}$ & $\begin{array}{c}0.162 \\
(0.013) * * * *\end{array}$ \\
\hline GARCH $1\left(\sigma_{t-1}^{2}\right)$ & $\begin{array}{c}0.825 \\
(0.009) * * * *\end{array}$ & $\begin{array}{c}0.826 \\
(0.010) * * * *\end{array}$ & $\begin{array}{c}0.825 \\
(0.009) * * * *\end{array}$ & $\begin{array}{c}0.824 \\
(0.010) * * * *\end{array}$ & $\begin{array}{c}0.823 \\
(0.009) * * * *\end{array}$ & $\begin{array}{c}0.824 \\
(0.010) * * * *\end{array}$ \\
\hline $\mathrm{N}$ & 1628 & 1628 & 1628 & 1587 & 1628 & 1628 \\
\hline $\begin{array}{l}\text { Wald chi } \\
\left(\text { Prob > chi }{ }^{2}\right)\end{array}$ & $\begin{array}{l}231.40 \\
(0.000) \\
\end{array}$ & $\begin{array}{l}241.81 \\
(0.000) \\
\end{array}$ & $\begin{array}{l}233.33 \\
(0.000) \\
\end{array}$ & $\begin{array}{l}231.58 \\
(0.000) \\
\end{array}$ & $\begin{array}{l}235.63 \\
(0.000) \\
\end{array}$ & $\begin{array}{l}246.44 \\
(0.000) \\
\end{array}$ \\
\hline Log likelihood & -1601.132 & -1601.016 & -1601.114 & -1583.370 & -1600.860 & -1600.288 \\
\hline
\end{tabular}

$* * * * \mathrm{p}<=0.001 ; * * * \mathrm{p}<=0.01 ; * * \mathrm{p}<=0.05 ; * \mathrm{p}<=0.1$

Table 3: Pooled GARCH First Differences Models. Dependent variable: Change in Real Interest Rate 
Table 3 supports our theoretical model. Changes in the key currency's interest rate have the assumed significant and positive effect on the decision of the EMU-outsiders to adjust their interest rates. This holds true for the whole period under observation. Most noteworthy, the effect increased significantly after the EMU central banks had harmonized their interest rates. Between 1973 and 1994 the five countries under observation shifted their real interest rate up by approximately 0.23 percentage points for every percent real interest increase by the German Bundesbank. In the period following the introduction of close monetary coordination between EMU central banks, the corresponding value was 0.31 percentage points. These results are robust across different model specifications. Hence, the influence of the key currency on the monetary policy of EMU outsiders is positively related to the size of the key currency area. Ironically, monetary policy autonomy - the main reason for abstaining from the union - decreases even in countries that abstained from joining the union.

Both, the growth rate of the countries in our sample and the German growth rate, appear to be positively related to the real interest rate differentials. However, although central banks apparently observe the macroeconomic situation in the key currency area, the estimated effect is rather small and never becomes significant.

The estimation of the variance equation reveals the necessity of controlling for autoregressive conditional heteroscedasticity. Both, the ARCH 1 and the GARCH 1 terms remain positive and significant in all models we ran. Obviously, interest rates are not only highly volatile over time, the variance at time $t$ also depends on the variance at $\mathrm{t}-1$. Ignoring this fact would have rendered estimates inefficient and most likely biased. Since the sum of the ARCH and the GARCH terms fall short of unity, our estimates conform to the stability condition for ARCH models. ${ }^{9}$ Finally, after having taken first differences and controlled for ARCH the remaining residuals are white noise.

To sum up: the empirical tests of the crucial assumption and of the implications of the model both lend support to our theoretical claims. De facto monetary autonomy of countries outside the European monetary union declined as a consequence 
of the harmonization of central bank policies in the EMU and - more importantly - as a consequence of the Euro introduction.

\section{Conclusion}

The ability of governments (and independent central banks) to set the prime interest rate according to the macroeconomic situation of the country is conditioned upon the degree of international monetary interdependence. The more important international production chains become, the more vulnerable countries are to exchange-rate volatility. As a consequence, governments increasingly have to rely upon one instrument - monetary policy - to reach two goals simultaneously: stable growth and stable exchange rates.

This paper advances our understanding of the role of currency unions for monetary policy autonomy in neighbouring countries. In particular, the exchange rate goal becomes more important for a country, the larger the size of the key currency area gets. Of course, significant changes in the relative size of key currency areas tend to be rare and moderate. But there is one exception to this rule: the formation of a currency union. If a nucleus of countries forms a new currency union, outsiders will experience a sudden increase in the need to stabilize exchange-rates. The de facto monetary policy autonomy therefore declines with the introduction of a currency union incorporating the former (regional) key currency. Nowadays, the prime interest rate of West European countries more closely follows the monetary policy agreed upon by the European Central Bank.

This novel perspective on monetary policy autonomy finds support in the data. Evidence for our theoretical claims is persuasive: The impact of monetary policy in the Eurozone on monetary policy in Great Britain, Sweden, Denmark, Norway and Switzerland, is about 25 percent higher than it was before the introduction of the Euro. However, despite having lost some monetary policy autonomy after the introduction of the Euro, this decline remains incomplete. Only the future can tell whether the decline is already far-reaching enough to render joining the union viable for outside countries.

If our model correctly mirrors the real world and if governments consider the efficiency gains of free trade, political leaders in countries outside (but geographically and economically close to) the currency union face three options: First, they 
may largely ignore the reduction of their monetary policy autonomy and stay outside the currency union. Countries are most likely to do so if trade with the union appears relatively unimportant, their business-cycle is only loosely synchronized with the union's cycle, exogenous shocks are frequent and domestic financial markets efficient. Second, governments may decide to join the union if the expected gains from joining exceed the loss in monetary policy autonomy. This option hinges on the degree to which governments have employed monetary policy autonomy as a strategic instrument in the past. If constituents have an anti-inflation bias and value low inflation rates relative to high consumption levels, governments are more likely to join the union. Finally, outsiders may institutionalize a competing currency union. This option seems preferable to groups of outsiders that already have closely synchronized business cycles.

Most likely, the expansion of a currency union in general and the Eurozone in particular will be stopped by insiders, not by outsiders. Old members of a currency union may have no interests in accepting membership applications even if outsiders are willing to give up their monetary autonomy. Accordingly, the optimal number of currencies will never approach one. With a growing heterogeneity of currency union members, a single country's political influence on the Union's monetary policies declines. Membership in a currency union becomes potentially more costly, the more members the union already has accepted. The political representation of each single country declines and political conflict intensifies with the desynchronization of the member's business cycles and thus with the number of members. This logic places a natural ceiling on the size of currency unions.

\section{Literature:}

Alesina, Alberto and Robert J. Barro 2002. 'Currency Unions', Quarterly Journal of Economics, 409-436.

Bayoumi, Tamin and Barry Eichengreen 1996, 'Optimum Currency Areas and Exchange Rate Volatility: Theory and Evidence', Working Paper, International Monetary Fund.

Bayoumi, Tamin and Barry Eichengreen 1996. 'Operationalizing the Theory of Optimum Currency Areas’ CEPR Working Papers.

Bayoumi, Tamin and Barry Eichengreen 1997 'Ever Closer to Heaven? An Optimum-Currency-Area Index for European Countries.' European Economic Review 41, 761-770. 
Broda, Christian and Eduardo Levi Yeyati, 2003. 'Dollarization and the Lender of Last Resort.' in: Levi Yeyati/ Sturzenegger (eds.): Dollarization. Debates and Policy Alternatives, MIT Press: Cambridge, 101-131.

Chang, Roberto and Andres Velasco 2000. 'Financial Fragility and the ExchangeRate Regime'. Journal of Economic Theory 92, 1-34.

Dixit, Avinash and Joseph Stiglitz1977. 'Monopolistic Competition and Optimum Product Diversity.' American Economic Review 67, 297-308.

Frankel, Jeffrey and Andrew Rose 1997. 'The Endogeneity of Optimum Currency Area Criteria', in: Swedish Economic Policy Review, 4, 489-512.

Kaminsky, Gracia and Carmen Reinhart 1999. 'The Twin Crises. The Causes of banking and Balance of Payments Problems'. American Economic Review $89,473-500$.

Levi Yeyati, Eduardo and Federico Sturzenegger 2003. 'Dollarization. A Primer'. in: Levi Yeyati/ Sturzenegger (eds.): Dollarization. Debates and Policy Alternatives, MIT Press: Cambridge, 1-51.

McCallum, Bennett T. 1996. 'Theoretical Issues Pertaining to Monetary Unions', NBER Working Paper 7393.

Minford, Peter. 1993. 'Other People's Money: The Microfoundations of Optimal Currency Areas.' CEPR Discussion Paper no. 757. London, Centre for Economic Policy Research. http://www.cepr.org/pubs/dps/DP757.asp.

McKinnon, Ronald 1963. 'Optimal Currency Areas'. American Economic Review 53, 717-725.

Metzler, Lloyd A. 1960. 'The Process of International Adjustment under Conditions of Full Employment. A Keynesian View', in: Richard Caves and Harry G. Johnson (ed.) Readings in International Economics, Richard D. Irwin, Homewood.

Mundell, Robert A. 1961. 'A Theory of Optimum Currency Areas'. American Economic Review 51, 657-665.

Mundell, Robert M. 1965 'Capital Mobility and Stabilization Policy under Fixed and Flexible Exchange Rates', Canadian Journal of Economics and Political Science, 29, 475-485

Persson, Torsten and Guido Tabellini 2000. Political Economics, MIT Press: Cambridge.

Phillips, Peter C. 1986. 'Understanding Spurious Regressions in Econometrics.' Journal of Econometrics, 33, 311-340.

Rose, Andrew, 2000. 'One Money One Market, Estimating the Effect of Common Currencies on Trade.' Economic Policy, 30, 9-48.

Shambaugh, Jay C. 2004. 'The Effect of Fixed Exchange Rates on Monetary Policy', Quarterly Journal of Economics 119, 301-352.

Wooldridge, Jeffrey M. (2003). Introductory Econometrics: a modern approach, Cincinnati: South Western College, second edition. 

Bücher des Forschungsschwerpunkts Markt und politische Ökonomie

Books of the Research Area Markets and Political Economy

Thomas Cusack

A National Challenge at the Local Level: Citizens, Elites and Institutions in Reunified Germany

2003, Ashgate

Sebastian Kessing

Essays on Employment Protection

2003, Freie Universität Berlin,

http://www.diss.fu-berlin.de/2003/202

Daniel Krähmer

On Learning and Information in Markets and

Organizations

2003, Shaker Verlag

\section{Bob Hancké}

Large Firms and Institutional Change. Industrial

Renewal and Economic Restructuring in France

2002, Oxford University Press

Andreas Stephan

Essays on the Contribution of Public Infrastructure to Private: Production and its Political

Economy

2002, dissertation.de

Peter A. Hall, David Soskice (Eds.)

Varieties of Capitalism

2001, Oxford University Press

Hans Mewis

Essays on Herd Behavior and Strategic

Delegation

2001, Shaker Verlag

Andreas Moerke

Organisationslernen über Netzwerke - Die

personellen Verflechtungen von

Führungsgremien japanischer

Aktiengesellschaften

2001, Deutscher Universitäts-Verlag

Silke Neubauer

Multimarket Contact and Organizational Design

2001, Deutscher Universitäts-Verlag

Lars-Hendrik Röller, Christian Wey (Eds.)

Die Soziale Marktwirtschaft in der neuen

Weltwirtschaft, WZB Jahrbuch 2001

2001, edition sigma

Michael Tröge

Competition in Credit Markets: A Theoretic

Analysis

2001, Deutscher Universitäts-Verlag

Torben Iversen, Jonas Pontusson, David Soskice

(Eds.)

Unions, Employers, and Central Banks

2000, Cambridge University Press
Tobias Miarka

Financial Intermediation and Deregulation:

A Critical Analysis of Japanese Bank-Firm-

Relationships

2000, Physica-Verlag

Rita Zobel

Beschäftigungsveränderungen und organisationales Lernen in japanischen Industriengesellschaften

2000, Humboldt-Universität zu Berlin

http://dochost.rz.hu-berlin.de/dissertationen/zobelrita-2000-06-19

Jos Jansen

Essays on Incentives in Regulation and

Innovation

2000, Tilburg University

Ralph Siebert

Innovation, Research Joint Ventures, and Multiproduct Competition

2000, Humboldt-Universität zu Berlin

http://dochost.rz.hu-berlin.de/dissertationen/siebertralph-2000-03-23/

Damien J. Neven, Lars-Hendrik Röller (Eds.)

The Political Economy of Industrial Policy in

Europe and the Member States

2000, edition sigma

Jianping Yang

Bankbeziehungen deutscher Unternehmen:

Investitionsverhalten und Risikoanalyse

2000, Deutscher Universitäts-Verlag

Christoph Schenk

Cooperation between Competitors -

Subcontracting and the Influence of Information,

Production and Capacity on Market Structure and

Competition

1999, Humboldt-Universität zu Berlin

http://dochost.rz.hu-berlin.de/dissertationen/schenk-

christoph-1999-11-16

Horst Albach, Ulrike Görtzen, Rita Zobel (Eds.)

Information Processing as a Competitive

Advantage of Japanese Firms

1999, edition sigma

Dieter Köster

Wettbewerb in Netzproduktmärkten

1999, Deutscher Universitäts-Verlag

Christian Wey

Marktorganisation durch Standardisierung: Ein

Beitrag zur Neuen Institutionenökonomik des

Marktes

1999, edition sigma 

Annette Boom

Kai A. Konrad Wolfram F. Richter

Stergios Skaperdas

Johan Lagerlöf

Roman Inderst

Christian Wey

Sebastian Kessing

Robert Nuscheler

Lars Frisell

Paul Heidhues Nicolas Melissas

Pablo Beramendi

Daniel Krähmer

Ralph Siebert

Vivek Ghosal

Vivek Ghosal

Andreas Blume

Paul Heidhues

Sebastian Kessing

Tomaso Duso Astrid Jung

Thomas R. Cusack Pablo Beramendi

Kjell Erik Lommerud Frode Meland Odd Rune Straume
Investments in Electricity Generating Capacity under Different Market Structures and with Endogenously Fixed Demand

Zur Berücksichtigung von Kindern bei umlagefinanzierter Alterssicherung

Restraining the Genuine Homo Economicus: Why the Economy cannot be divorced from its Governance

Insisting on a Non-Negative Price: Oligopoly, Uncertainty, Welfare, and Multiple Equilibria

Buyer Power and Supplier Incentives

SP II $2003-02$

SP || $2003-03$

SP || $2003-04$

SP II $2003-05$

Monopoly Pricing with Negative Network Effects:

The Case of Vaccines

The Breakdown of Authority

SP || $2003-07$

Equilibria in a Dynamic Global Game: The Role of Cohort Effects

Political Institutions and Income Inequality:

The Case of Decentralization

Learning and Self-Confidence in Contests

SP || $2003-10$

SP || $2003-11$ Incumbent Firms: Market Proliferation versus Cannibalization

Impact of Uncertainty and Sunk Costs on Firm Survival and Industry Dynamics

Endemic Volatility of Firms and Establishments:

Are Real Options Effects Important?

Private Monitoring in Auctions

SP || $2003-14$

Delay in Joint Projects

SP || $2003-15$

Product Market Competition and Lobbying

SP || $2003-16$

Coordination in the U.S. Mobile

Telecommunications Industry

Taxing Work: Some Political and Economic

SP || $2003-17$ Aspects of Labor Income Taxation

Globalisation and Union Opposition to Technological Change
SP || $2003-18$ 
Joseph Clougherty

Dan Anderberg Fredrik Andersson

Eugenio J. Miravete Lars-Hendrik Röller

Talat Mahmood Klaus Schömann

Talat Mahmood Klaus Schömann

Suchan Chae Paul Heidhues

Sigurt Vitols

Michal Grajek

Kai A. Konrad

Helmut Bester

Kai A. Konrad

Kai A. Konrad

Kai A. Konrad

Steffen Huck Kai A. Konrad
Industry Trade-Balance and Domestic Merger

Policy: Some Empirical Evidence from the U.S.

Stratification, Social Networks in the Labour Market, and Intergenerational Mobility

Estimating Markups under Nonlinear Pricing Competition

On the Migration Decision of IT-Graduates:

A Two-Level Nested Logit Model

Assessing the Migration Decision of Indian

IT-Graduates: An Empirical Analysis

Buyers Alliances for Bargaining Power

Negotiated Shareholder Value: The German Version of an Anglo-American Practice

Estimating Network Effects and Compatibility in Mobile Telecommunications

Bidding in Hierarchies

Easy Targets and the Timing of Conflict

Opinion Leaders, Influence Activities and Leadership Rents

Mobilität in mehrstufigen Ausbildungsturnieren

Moral Cost, Commitment and Committee Size
SP || $2003-19$

SP II $2003-20$

SP || $2003-21$

SP || $2003-22$

SP || $2003-23$

SP || $2003-24$

SP I| $2003-25$

SP || $2003-26$

SP || $2003-27$

SP || $2003-28$

SP || $2003-29$

SP || $2003-30$

SP || $2003-31$ 
Jos Jansen

Johan Lagerlöf

Lars Frisell

Sigurt Vitols

Lutz Engelhardt

Antonio Guarino

Steffen Huck Thomas D. Jeitschko

Thomas Plümper Vera E. Troeger
Partial Information Sharing in Cournot Oligopoly

Lobbying, Information Transmission, and Unequal Representation

Changes in Germany's Bank Based Financial System: A Varieties of Capitalism Perspective

Entrepreneurial Business Models in the German Software Industry: Companies, Venture Capital, and Stock Market Based Growth Strategies of the ,Neuer Markt'

Can Fear Cause Economic Collapse? Insights from an Experimental Study

SP || $2004-05$

External Effects of Currency Unions
SP || $2004-06$

SP II $2004-01$

SP || 2004-02

SP || $2004-03$

SP || $2004-04$ 

Bei Ihren Bestellungen von WZB-Papers schicken

Sie bitte unbedingt einen an Sie adressierten Auf-

kleber mit sowie je paper eine Briefmarke im Wert

von 0,51 Euro oder einen "Coupon Reponse Inter-

national " (für Besteller aus dem Ausland)
Please send a self addressed label and postage stamps in the amount of 0.51 Euro or a "CouponReponse International" (if you are ordering from outside Germany) for each WZB-paper requested

Absender / Return Address:

Wissenschaftszentrum Berlin

für Sozialforschung

Presse- und informationsreferat

Reichpietschufer 50

D-10785 Berlin-Tiergarten

Hiermit bestelle ich folgende(s)

Discussion paper(s):

Please send me the following Discussion paper(s):

Bestell-Nr. / Order no.

Autor/in, Kurztitel /Author(s) / Title(s) in brief 